\title{
Integrated Surface and Subsurface Studies for Water Resources Evaluation in Wadi Dahab Basin, Sinai, Egypt
}

\author{
Ibrahim Salaheldin Khedr ${ }^{1}$, Eman Abdel-Hameid ${ }^{2}$ and Osama Abdel-Raouf ${ }^{3}$ \\ 1. Head of GIS unit, Canals Maintenance Research Institute(CMRI), National Water Research \\ Centre(NWRC), Egypt \\ 2. Lecturer in Dept. of Geography, Faculty of Arts, Benha University. \\ 3. Prof. of geophysics, Water Recourses Research Institute(WRRI), National Water Research \\ Centre(NWRC), Egypt
}

Keywords: Wadi Dahab - Groundwater - GIS - Geo-electric survey Geomorphology - Potentiality.

\footnotetext{
إصدار سبتمبر لسنة 2017م

شعبة البحوث الجغرافية
} 


\section{Abstract:}

The integration between different studies contributing to the clear vision is curtail planners and decision makers. The GIS technique is an effective tool that can analyze the multi-data from the different sources. This paper aims to study the integration between the surface and subsurface studies to evaluate the water resources for enhancing in the master plan of the sustainable development of the study area.

The hydrological studied of drainage basins help in calculating the amounts of runoff, and the morphometric analysis of the drainage network lead to detecting the paths and direction of surface water. From the subsurface point of view, the geoelectric resistivity technique of geophysical investigation is applied for identifying the physical properties of the subsurface setting by extracting a set of maps for the aquifer properties'. In addition, the geoelectric subsurface sections were used in creating a morphological map for the top surface of basement rock, therefore the water paths under the surface was delineated.

A set of maps are constructed based on the vertical and lateral cross sections that induced from analysis of aeromagnetic and resistivity data. In addition, to the structural features that affected the groundwater behavior.

Results indicated that the integration of these two types of applications give a real imagination about the subsurface behavior of ground water through different kinds of surface and subsurface mapping. These maps display areas that suitable for agriculture, touristic activities and urban expansion and can be used as an input data for master plans of the area development strategies.

\section{Introduction:}

Recently, the coastal areas have witnessed developmental programs of land reclamation, agricultural, touristic and industrial plans. Most of the environmental and developmental studies that have been conducted on the coastal area of the Gulf of Aqaba have not led to an integrated coastal information system and did not give a clear discussion concerning the problems and hazards that threaten the developmental plans in this coastal strip. The developmental planning of the coastal areas is mainly governed by many factors, mainly geomorphology, hydrogeology, prevailed structures and ecosystems. Therefore, the sustainable development needs an integration of Surface and Subsurface information. 
The most characteristic features of the Gulf of Aqaba coastal area are moderate-sloping and narrow plain. In southwestern Sinai, and especially along the Gulf of Aqaba, where the study area is located, tourist villages that concentrated at the alluvial fans are growing at fast pace, and the average water consumption is rising. So, this distinguished locality at the southwestern Sinai area attracts our attentions to carry out this research to participate the decision makers and managers for the developing programs in this specified area. This research concerned with Wadi Dahab basin which lies on the southern part of Gulf of Aqaba.

Dahab basin is a part of south Sinai and characterized by rugged topography due to continuous erosion and development of the drainage pattern (Khadra, 2008). The area under investigation comprises the southeastern coastal area of the Gulf of Aqaba. It is located approximately between longitudes 3400 and $34^{\circ} 30 \mathrm{E}$ and latitudes $28^{\circ} 00$ and $28^{\circ} 45 \mathrm{~N}$ (Fig. 1). It is accessible by a good network of paved roads and tracks.

This study was carried out by applying surface geomorphological, Soil, Geological and Drainage density mapping in addition to subsurface geophysical investigation through geo-electric resistivity survey techniques to identify the subsurface rock sequence, water-bearing layers, and shed more light on the structural trends that control the groundwater movement in the study area and the depth of the sedimentary cover in the selected wadis.

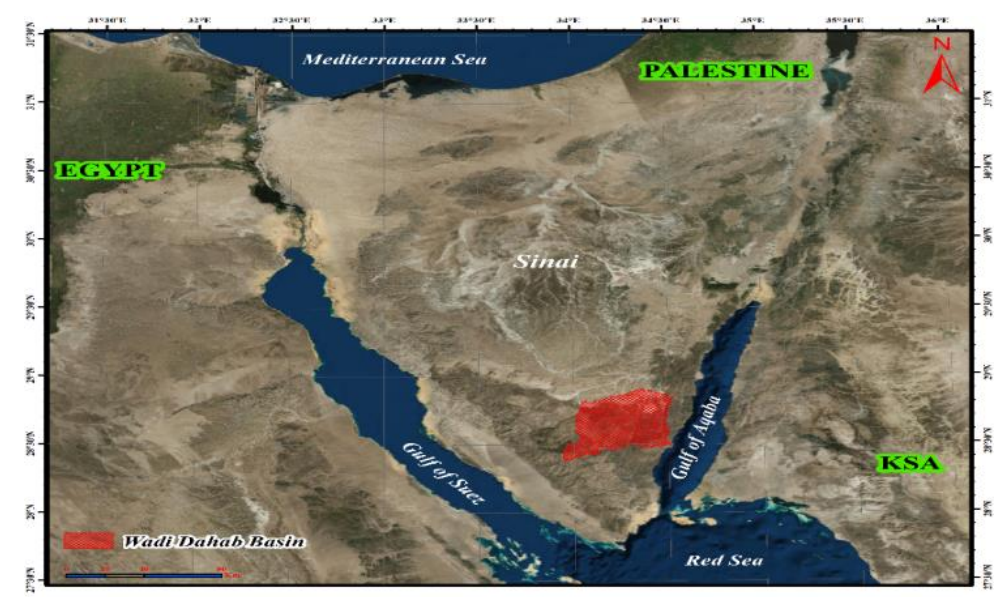

Fig. 1. Location map of Study area 


\section{Surface Study}

Interpretation of surface remotely sensing data is considered as qualitative characterization of hydrological mapping units and specific features. Many applications pertain to groundwater emergence in the area of discharge and flow systems where the topography plays an important role in the surface runoff.

\subsection{Geomorphological Setting}

The relief interval of wadi Dahab is 2,481 meters, where it starts from zero at Sabkha Dahab near the coast line and gradually rises westward. The fan apex at the wadi exit is 38 meters and increases gradually to more than 2000 meters in the southwestern parts of the basin (Fig. 2).

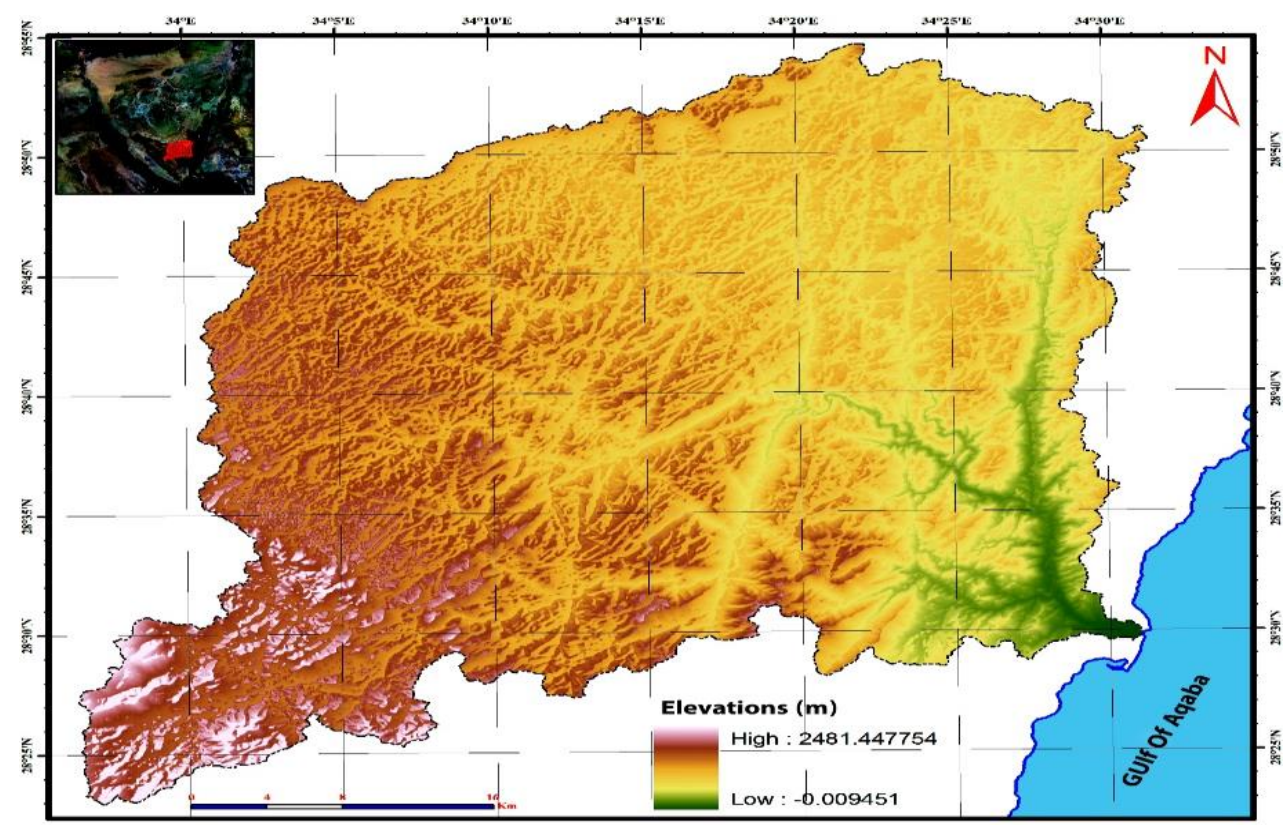

Fig. 2. Morphological map of wadi dahab basin

The basin includes many land forms of various origins, mostly due to the erosion and sediment by runoff water. The most important geomorphologic features are; streams, alluvial cones, alluvial fans and isolated hills. The wind plays a secondary role on the modification of the geomorphological forms in addition to the formation of small features on the surface of Dahab fan and sub-wadis fans. Also the area includes some 
geomorphological units of marine origin such as dahab sabkha in south of dahab city, and the magic lake which is formed originally by coral reef. Moreover, the Alluvial fan of dahab basin bordered by a coral reef ring.

\subsection{Geologic Setting}

According to the Egyptian Geological Survey (EGSMA, 1993) the geology of the Sinai area ranges from Precambrian basement rocks to the Quaternary deposits. The Quaternary deposits cover the basement rocks along the Gulf of Suez and Gulf of Aqaba.

The basement rocks (Precambrian) occupy the southern part of Sinai peninsula, along the Gulf of Suez and Gulf of Aqaba. On the other hand, the Palaeozoic rocks are present in the middle part while the Mesozoic rocks covered the eastern and western parts of the area. The southern Sinai composed mainly of basement rocks, (Hume, 1906, Said, 1962). It consists mainly of metamorphic granites and volcanic rocks forming a dissected plateau that slopes gently toward the north with the overlying sedimentary rocks from Pre-Cambrian to recent.

The most remarkable tectonic structure in southern Sinai is Ragabet El Naam fault which extends from El Naqab in the east to Sudr El Hietan in the west. There are many types of faults in South Sinai directed to the Gulf of Aqaba and Gulf of Suez. These faults or fractures play an important role in surface water and groundwater resources evaluation (Fig.3). El Agami (1996) indicated that faulting plays the main role in the tectonic framework of the Sinai Peninsula having the following trends NNW, NW and NS with NNE to NE and ENE trends as a subordinate ones, These faults are high angle normal listric type. The Precambrian rocks of Sinai are highly dissected by dry valleys that are filled by a wide variety of stream sediments. 


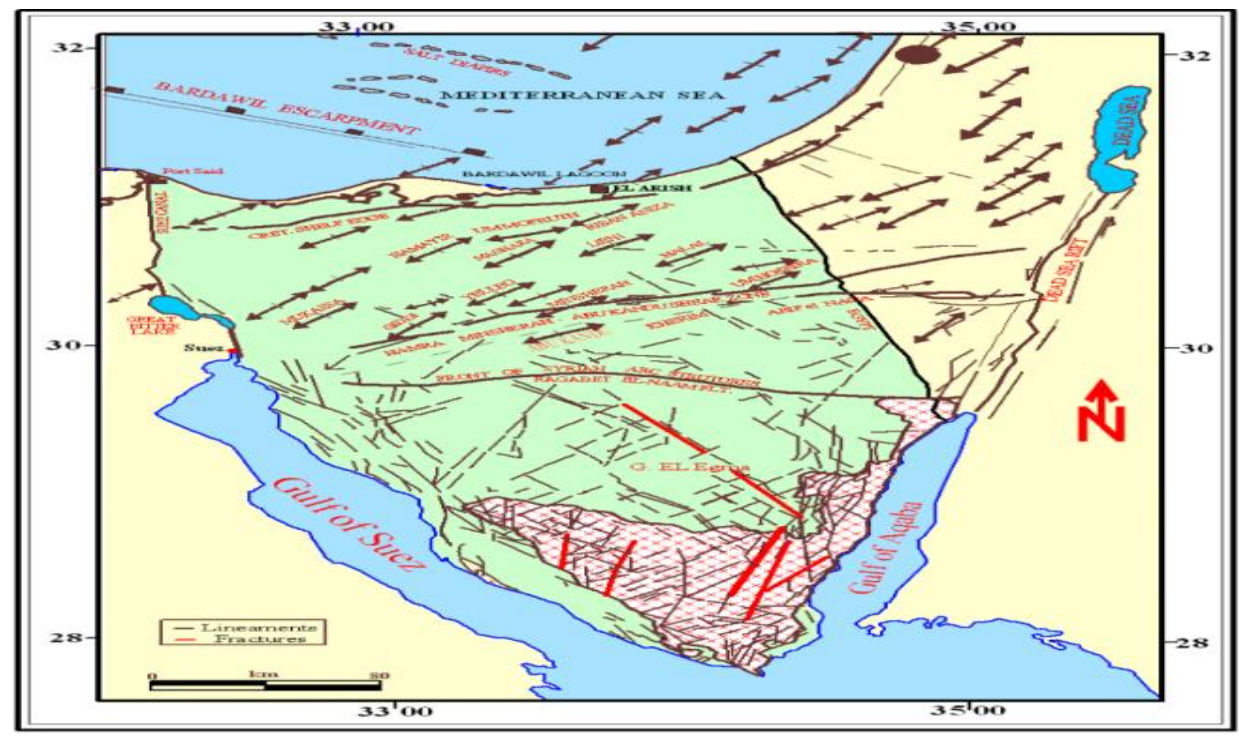

Fig. 3. Tectonic map of Sinai, (after, Agah, 1981)

The sedimentary successions in the study area are mainly represented by clastic sediments comprising sandstones and wadi deposits. The sandstones are either Cambrian or Cenomanian and they are adjacent to the Precambrian crystalline rocks along structural contacts, namely nonconformities and graben faults (Surour et al., 2003). On the other hand, wadi deposits are much younger in age and they range from Quaternary to Recent. They are stratigraphically discriminated into lacustrine and fluviatile deposits (wadi terraces), alluvial fans and loose sand. The wadi terraces ranges in thickness from 1.5 to $9 \mathrm{~m}$ and sometimes they show evidences of change in the current direction and power as indicated by the development of cross-bedding. Sediments of channel fillings at the middle of the stream course as well as the alluvial fans show some other primary sedimentary structures like graded-bedding.

In general, the sediments of channel fillings at Dahab basin are much more mineralogically immature than both the terraces and fans. All types of the investigated wadi deposits contain numerous pebbles, cobbles and boulders of granitic and volcanic rocks (Surour et al., 2003). The geology of Dahab basin consists of rock units ranging in age from recent to PreCambrian (Fig.4). 


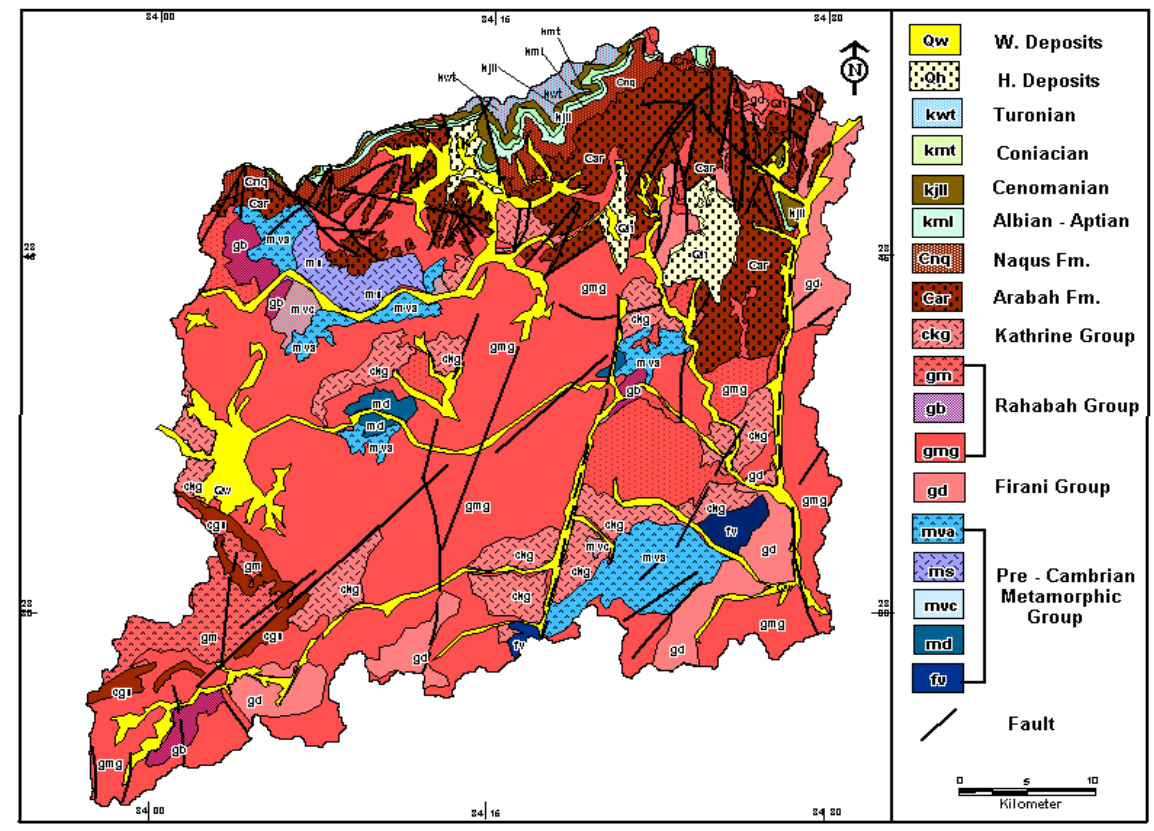

Fig. 4. Simplified geologic map of the study area

\subsection{Drainage Analysis}

The study of drainage basins and networks aims at identifying their morphometric, morphological, and surface characteristics and their discharge capacity, which can determine the quantities of precipitation and the probability of the occurrence of a runoff.

The topographic maps of scale 1:50000 was used in delineation of the sub-basins and Digitizing the network steams system based on Steller's method (Strahler, 1960, P 142) in the coding process of the morphometric network analysis. A study of the drainage network of Wadi Dahab basin showed that the number of wadis forming the valley network reached 7,792 tiers. The first rank constituted about $23 \%$ of the total number of ranks, and according to the previous method Strahler reached eight grades (Fig.5). 


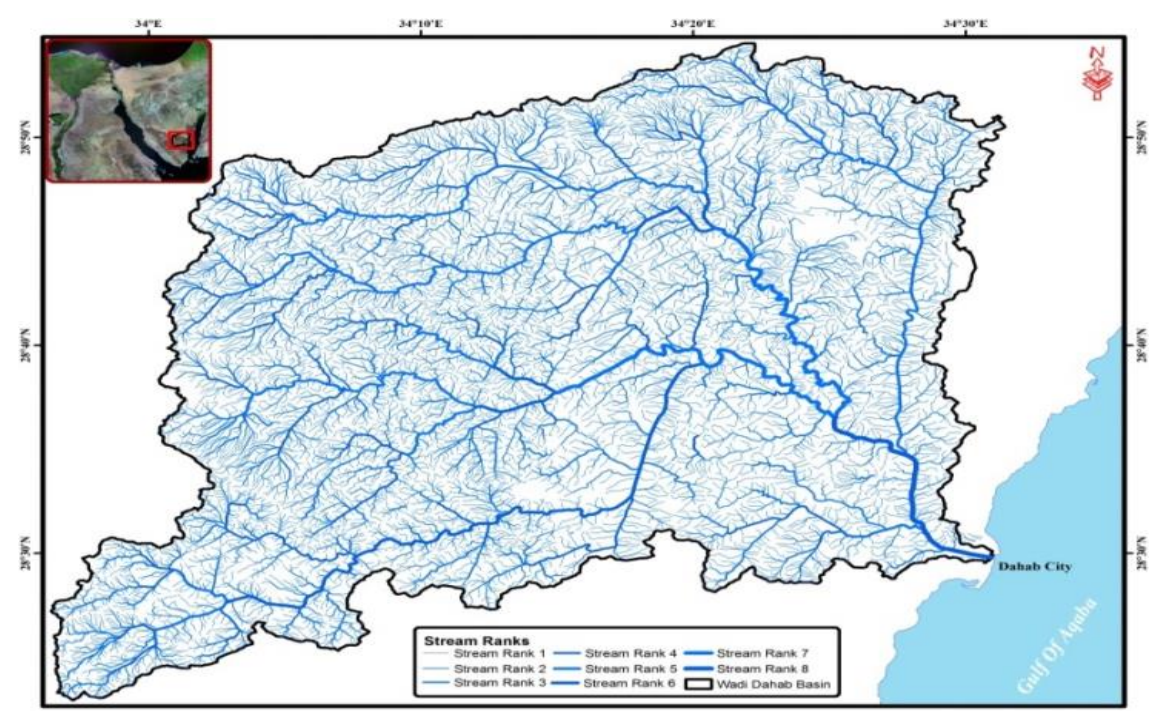

Fig. 5. Stream Network of wadi dahab

The area consists of high complex and complex igneous rocks and metamorphic rocks intersected by many faults differs in their orientation and extends; this complicated structure affected on the directions of different wadis. Analysis of this basin indicated that it consists of seven sub-basins, Wadi Nasab 445.8 km2, Wadi Zaghraa 414.4 km2, Wadi Al-Ghaeeb 300 km2, Wadi Al-Morrah 283.7 km2, Wadi Dahab (The Main Downstream) $273.1 \mathrm{~km} 2$, Wadi Saail, $224.4 \mathrm{~km} 2$ and Wadi Maeen $107.3 \mathrm{~km} 2$. This led to Enlargement of his alluvial fan which has an area equal 7.7-km2 (Fig.6).

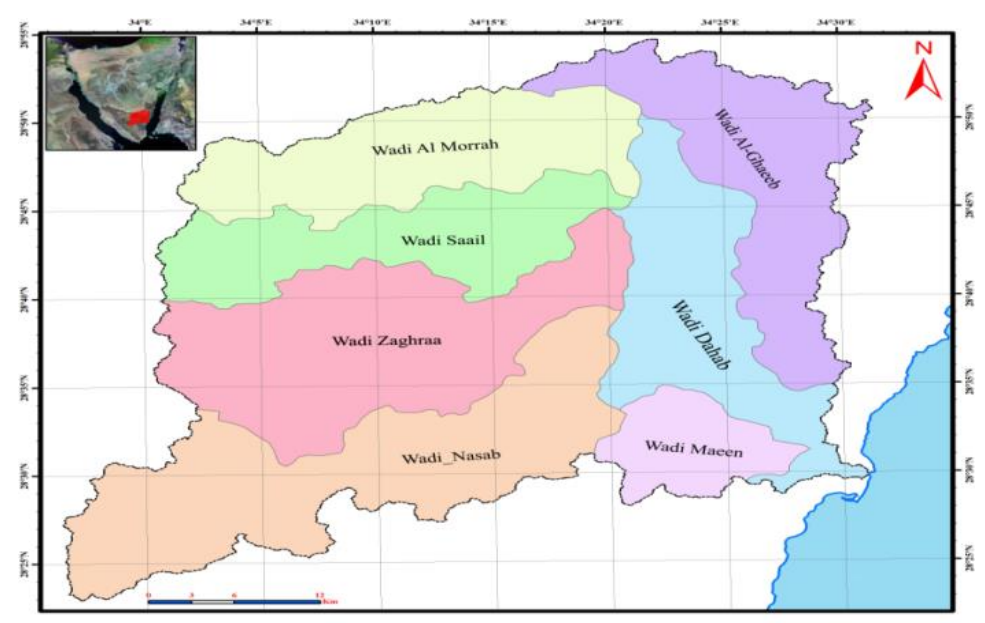

Fig. 6. The Sub-basin of wadi dahab 


\section{Subsurface Study}

To identify the natu)re and thickness of the lithological succession beneath the ground surface and the suitable areas for collecting the surface water, deep subsurface resistivity sounding was carried out to explore the water bearing formations (strata or aquifers) and to study the Effect of the subsurface structures (faults \& joints) on the investigated intervals.

\section{3-1 Electric Resistivity Measurements}

The basic principles of the geoelectrical resistivity techniques have been discussed by many authors among them. Flathe (1976), Parasnis (1979), Zohdy et al. (1974), Telford, et al., (1990) and Apparao (1991). The field geoelectrical survey comprises 32 VES using Schlumberger electrode configuration and their locations are shown in (Fig.7). At each VES location, the distance between the potential electrodes was increased only few times (from 0.5 to $200 \mathrm{~m}$ ) while the current electrode separation was increased from 1.5 up to $100 \mathrm{~m}$ and to $1000 \mathrm{~m}$ in some VES.

Analysis of electrical resistivity measurements, when accompanied by suitable geologic information can permit determination of groundwater occurrence and structural features that control the water-bearing strata within any area.

Application of electrical resistivity methods includes prospecting for resistive materials, structural investigations, delineating saline and fresh water -bearing zones, geothermal exploration, ... etc ( Telford, et. al ., 1990).

The resistivity survey was carried out through conducting about 50 Vertical Electrical Sounding (VES) using Schumberger configuration with a maximum current electrode spacing of about 800 meter. These VES's was arranged in profiles covering the promising wadis and the delta of the basin and sub-basins (Fig. 7)

\subsection{Interpretation of Resistivity Sounding Data.}

The interpretation of the acquired resistivity sounding data is carried out both qualitatively and quantitatively to represent the horizontal and vertical distribution of true resistivity of the subsurface lithologic units. 
Iterative and indirect procedure is used to invert resistivity data. The basic theory of this technique is assuming the subsurface model consisting of a finite number of layers separated by horizontal interface. Each layer is electrically homogeneous and isotropic and has a finite thickness, except for the deepest layer, which extends to infinite depth. For such a model, Koefoed (1979) has shown that a function (the resistivity transform function) can be obtained such that it contains all the subsurface model parameters (resistivity and thickness).

For such purpose, a computer program called (RESIX-P) developed by INTERPEX LIMITED (1996) was used. To demonstrate the distribution of the calculated resistivity parameters (true resistivity and thickness) in the horizontal and vertical planes across the study area, eleven geoelectric resistivity cross-sections are constructed covering the study area. Locations of these sections are shown in (Fig.7), however, figures (Fig. 10, 11, 12 and 13) show four of these sections, hereunder detailed inspection of these section.

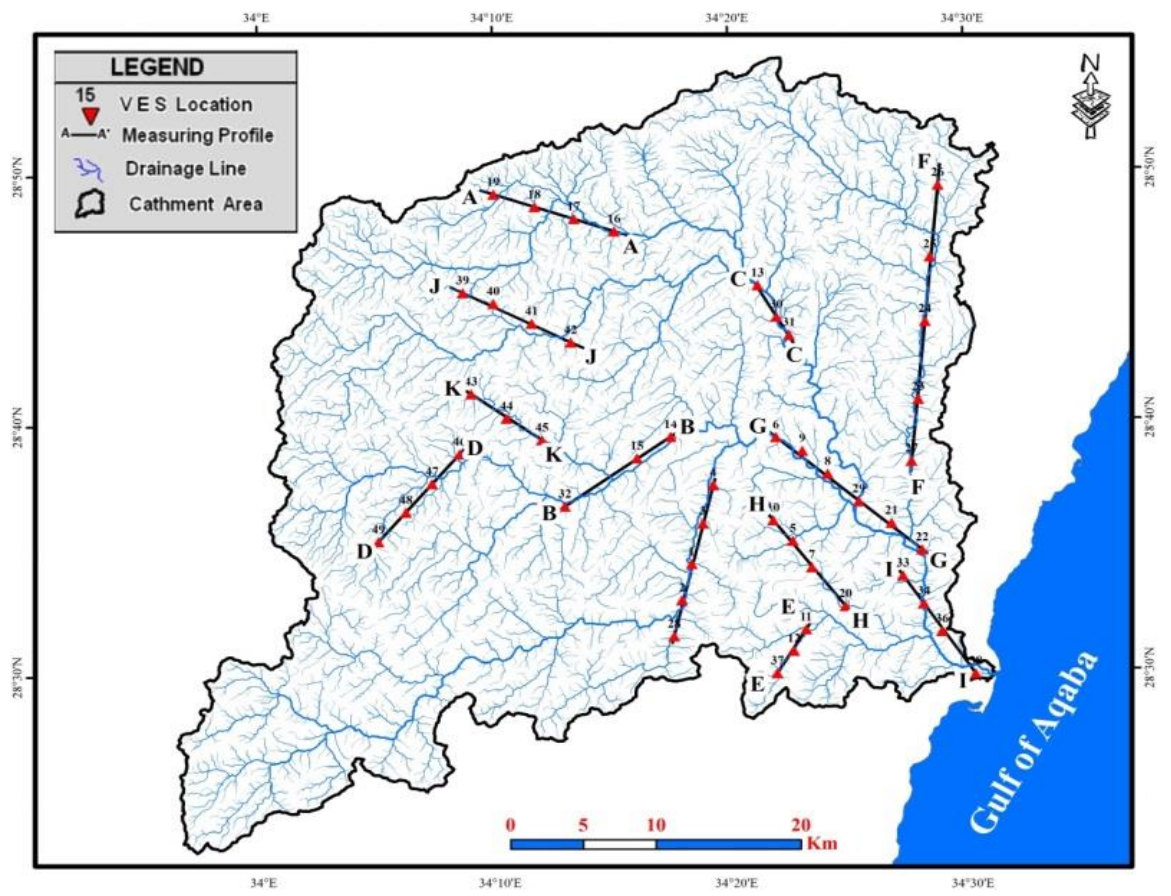

Fig. 7. Location of Resistivity Profiles 


\section{Results and Discussion}

Integration of the above surface and subsurface investigations helped in constructing surface maps and subsurface Geoelectric sections. These maps and sections describs the physical properties of the subsurface succession, groundwater potentiality and soil availability distribution

\subsection{Drainage Analysis}

General description of this map (Fig.5) refers that Wadi Dahab reached to the eights rank according to Strahler, (1964) as shown in Table (1). It indicated that the first rank constitutes about $68 \%$ of the total rank count, and the length of this rank reached $55 \%$ of total length. This means that Wadi Dahab can be considered as an active wadi.

Table (1): Ranks, Count, and Lengths of the Network Streams

\begin{tabular}{|c|c|c|c|c|c|c|c|c|c|c|c|c|c|c|c|c|c|c|}
\hline \multirow{2}{*}{ Basin } & \multicolumn{2}{|c|}{ Rank 1} & \multicolumn{2}{|c|}{ Rank 2} & \multicolumn{2}{|c|}{ Rank 3} & \multicolumn{2}{|c|}{ Rank 4} & \multicolumn{2}{|c|}{ Rank 5} & \multicolumn{2}{|c|}{ Rank 6} & \multicolumn{2}{|c|}{ Rank 7} & \multicolumn{2}{|c|}{ Rank 8} & \multirow{2}{*}{$\begin{array}{c}\text { Tot } \\
\text { al } \\
\text { of } \\
\text { Co } \\
\text { unt } \\
\text { s }\end{array}$} & \multirow{2}{*}{$\begin{array}{c}\text { Tot } \\
\text { al } \\
\text { of } \\
\text { Len } \\
\text { gth } \\
\text { s }\end{array}$} \\
\hline & $\begin{array}{c}c \\
o \\
u \\
n t\end{array}$ & $\begin{array}{l}\mathrm{L} \\
\mathrm{e} \\
\mathrm{n} \\
\mathrm{gt} \\
\mathrm{h}\end{array}$ & $\begin{array}{c}\mathrm{C} \\
\mathrm{o} \\
\mathrm{u} \\
\mathrm{nt}\end{array}$ & $\begin{array}{l}\mathrm{L} \\
\mathrm{e} \\
\mathrm{n} \\
\mathrm{gt} \\
\mathrm{h}\end{array}$ & $\begin{array}{c}\mathrm{C} \\
\mathrm{o} \\
\mathrm{u} \\
\mathrm{nt}\end{array}$ & $\begin{array}{l}\text { Le } \\
\mathrm{n} \\
\mathrm{gt} \\
\mathrm{h}\end{array}$ & $\begin{array}{c}\mathrm{C} \\
\mathrm{o} \\
\mathrm{u} \\
\mathrm{nt}\end{array}$ & $\begin{array}{l}\text { Le } \\
\mathrm{n} \\
\mathrm{gt} \\
\mathrm{h}\end{array}$ & $\begin{array}{c}\mathrm{C} \\
\mathrm{o} \\
\mathrm{u} \\
\mathrm{nt}\end{array}$ & $\begin{array}{l}\text { Le } \\
\mathrm{n} \\
\mathrm{gt} \\
\mathrm{h}\end{array}$ & $\begin{array}{c}\mathrm{C} \\
\mathrm{o} \\
\mathrm{u} \\
\mathrm{nt}\end{array}$ & $\begin{array}{l}\text { Le } \\
\mathrm{n} \\
\mathrm{gt} \\
\mathrm{h}\end{array}$ & $\begin{array}{c}\mathrm{C} \\
\mathrm{o} \\
\mathrm{u} \\
\mathrm{nt}\end{array}$ & $\begin{array}{c}\text { Le } \\
\mathrm{n} \\
\mathrm{gt} \\
\mathrm{h}\end{array}$ & $\begin{array}{c}\mathrm{C} \\
\mathrm{o} \\
\mathrm{u} \\
\mathrm{nt}\end{array}$ & $\begin{array}{l}\text { Le } \\
\text { n } \\
\text { gt } \\
\text { h }\end{array}$ & & \\
\hline Nasab & 1198 & 533.6 & 568 & 215.2 & 62 & 113.8 & 16 & 50.9 & 2 & 10.7 & 1 & 47.6 & & & & & 1847 & 971.8 \\
\hline Zaghraa & 1035 & 489 & 322 & 225.3 & 47 & 112.1 & 15 & 51.5 & 3 & 33.1 & 1 & 18 & & & & & 1423 & 929 \\
\hline Al-Ghaeeb & 812 & 393.6 & 387 & 149.6 & 76 & 73.2 & 10 & 31.4 & 1 & 41.8 & & & & & & & 1286 & 689.6 \\
\hline Al-Morrah & 765 & 391.6 & 376 & 167.6 & 135 & 66.9 & 11 & 44.2 & 3 & 21.8 & & & & & & & 1290 & 692.1 \\
\hline Dahab & 717 & 333 & 121 & 116.3 & 23 & 62.4 & 12 & 30.2 & 3 & 11.5 & & & 2 & 37.7 & 8 & 19 & 886 & 610.1 \\
\hline Saail & 599 & 305.4 & 171 & 135.4 & 29 & 49.3 & 7 & 31.5 & 2 & 32.5 & 1 & 7.22 & & & & & 809 & 561.32 \\
\hline Maeen & 291 & 126.7 & 123 & 43.6 & 12 & 27.4 & 4 & 20.3 & 1 & 8.8 & & & & & & & 431 & 226.8 \\
\hline Average & 5417 & $\begin{array}{c}2572 . \\
9\end{array}$ & 2068 & 1053 & 384 & 505.1 & 75 & 260 & 15 & 160.2 & 3 & 72.82 & 2 & 37.7 & 8 & 19 & 7972 & 4680.72 \\
\hline
\end{tabular}

Moreover, the summation of ranks 4,5,6,7 and 8 lengths constitute about $549.7 \mathrm{Km}$. That equivalent to $11.75 \%$ of the total length. This reflects that the elongation of the wadi. 


\subsection{Flow Volume}

According to the surface investigation of topography and climatic conditions, the parameters of total area, average rainfall, slopes, the permeability and the evaporation rates were used in applying the Graf's equation (1988) to calculate the volume of flow water. Results (Table 2) showed that the total volume of water reached about 25.6 million $\mathrm{m} 3$ / year.

Table (2) Results of Graf's Equation

\begin{tabular}{|c|c|c|}
\hline Basin & Area (Km2) & Volume (m3/y) \\
\hline Nasab & 445.8 & 5583645 \\
\hline Zaghraa & 414.4 & 5190360 \\
\hline Al-Ghaeeb & 300 & 3757500 \\
\hline Al-Morrah & 283.7 & 3553343 \\
\hline Dahab & 273.1 & 3420578 \\
\hline Saail & 224.4 & 2810610 \\
\hline Maeen & 107.3 & 1343933 \\
\hline Average & 292.6714 & 25659968 \\
\hline
\end{tabular}

\subsection{Soil map}

The soil in wadi Dahab is concentrated in Wadi El-Ghaieb and the lower part of Wadi Dahab where the wide area and the alluvial fan which reaches about $7.7 \mathrm{~km} 3$. the soil was classified as alluvial soil consists of sand, gravel and limestone.

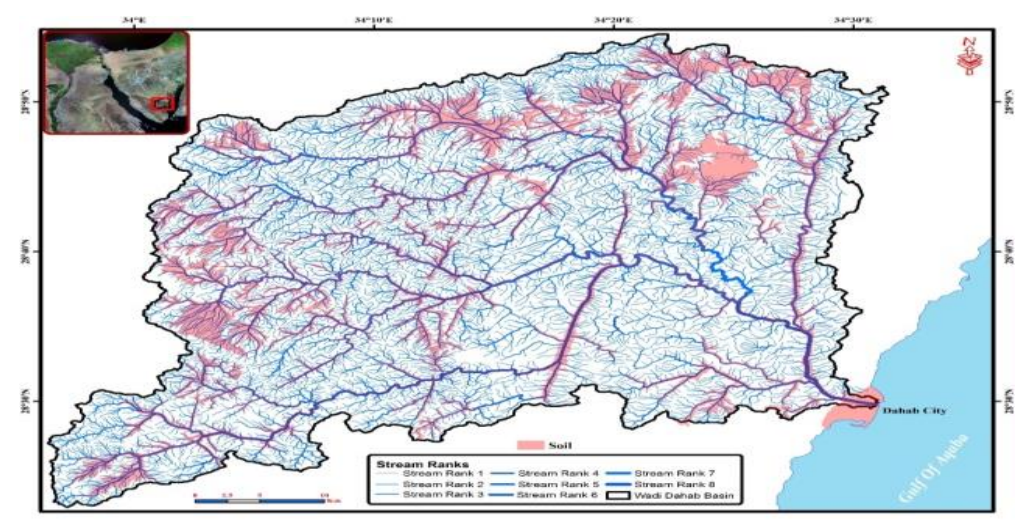

Fig. (8): Soil map of the study area 
The subsurface investigation of aquifer properties and the soil map (Figure 8) indicated that most of wadi basins are suitable for agriculture due its near to the aquifer.

Investigation of Wadi dahab alluvial fan was done through 6 samples collected from different sites where, analysis of fan deposits represents the dominant geomorphologic processes through the basins and the source rocks in addition to the distance of their gradients (El Tohami 1994). results of such investigations were shown in Table (3)

Table (3): Classification of Wadi dahab fan Deposits

\begin{tabular}{|c|c|c|c|c|c|c|c|c|c|c|}
\hline \multirow{2}{*}{$\begin{array}{c}\text { Sampl } \\
\text { e } \\
\text { Locati } \\
\text { on }\end{array}$} & \multirow{2}{*}{$\begin{array}{l}\mathrm{C} \\
\mathrm{o} \\
\mathrm{u} \\
\mathrm{nt} \\
\text { of } \\
\mathrm{Sa} \\
\mathrm{m} \\
\mathrm{pl} \\
\mathrm{es}\end{array}$} & \multirow{2}{*}{$\begin{array}{c}\text { Sam } \\
\text { ple } \\
\text { No. }\end{array}$} & \multirow{2}{*}{$\begin{array}{c}\text { Wei } \\
\text { ght } \\
\text { of } \\
\text { Sam } \\
\text { ple } \\
\text { (gr) }\end{array}$} & \multirow{2}{*}{$\begin{array}{c}\text { Dep } \\
\text { th } \\
(\mathrm{Cm} \\
1\end{array}$} & \multirow{2}{*}{ Gravel } & \multicolumn{3}{|c|}{ Sand } & \multirow{2}{*}{$\begin{array}{l}\text { Silt } \\
\text { and } \\
\text { clay }\end{array}$} & \multirow{2}{*}{ Total } \\
\hline & & & & & & $\begin{array}{c}\text { Coars } \\
\mathrm{e}\end{array}$ & Mid & Soft & & \\
\hline Apex & 1 & 6 & 100 & 30 & 32.8 & 26.4 & 19 & 15.7 & 6.1 & 100 \\
\hline \multirow[b]{2}{*}{ Mid } & \multirow[b]{2}{*}{2} & 5 & 100 & 30 & 28 & 23.1 & 20.1 & 18.4 & 10.1 & 99.7 \\
\hline & & 4 & 100 & 30 & 30 & 21.3 & 19.7 & 21 & 8.1 & $\begin{array}{c}100 . \\
1\end{array}$ \\
\hline \multirow{3}{*}{ Foot } & \multirow{3}{*}{3} & 3 & 100 & 30 & 13.2 & 26 & 30.3 & 25.1 & 5.1 & 99.7 \\
\hline & & 2 & 100 & 30 & 11.8 & 27.1 & 22.7 & 31.5 & 6.1 & 99.2 \\
\hline & & 1 & 100 & 30 & 7.8 & 20.8 & 33.1 & 31 & 7.3 & 100 \\
\hline
\end{tabular}

However, the characteristics of the internal structure of Wadi Dahab fan through the field study was identified during the road construction in the area exposed the vertical section of the fan deposits (fig. 9). The total length of the head section of the fan was about $180 \mathrm{~cm}$, and can be divided into six sections from top to bottom as follows:

The first section: The upper surface of the fan is $20 \mathrm{~cm}$ thick, characterized by the dominance of coarse sediments of large gravel and zebra with sharp angles, indicating the occurrence of a strong silky flow inspected by a short period of time. This section is considered as poor sedimentation classification. The second section: $15 \mathrm{~cm}$ thick and consists of medium-sized, semi-circular deposits of sand and gravel of good classification. Sediments appear in parallel to the water flow. This indicates 
a more systematic flow of water during the sedimentation of this section, which led to its rotation.

The third section: The average thickness of this section is $43 \mathrm{~cm}$ and consists of small, medium and semi-circular rough deposits, indicating the strength of the flow of liquid and the flow of dispersions. The fourth section has a thickness of about $35 \mathrm{~cm}$, and consists of deposits of gravel, sand and silt. Most of the sediment is almost round, and tends to reddish brown. This layer is characterized by good classification, that reflects its transfer by regular flow processes.

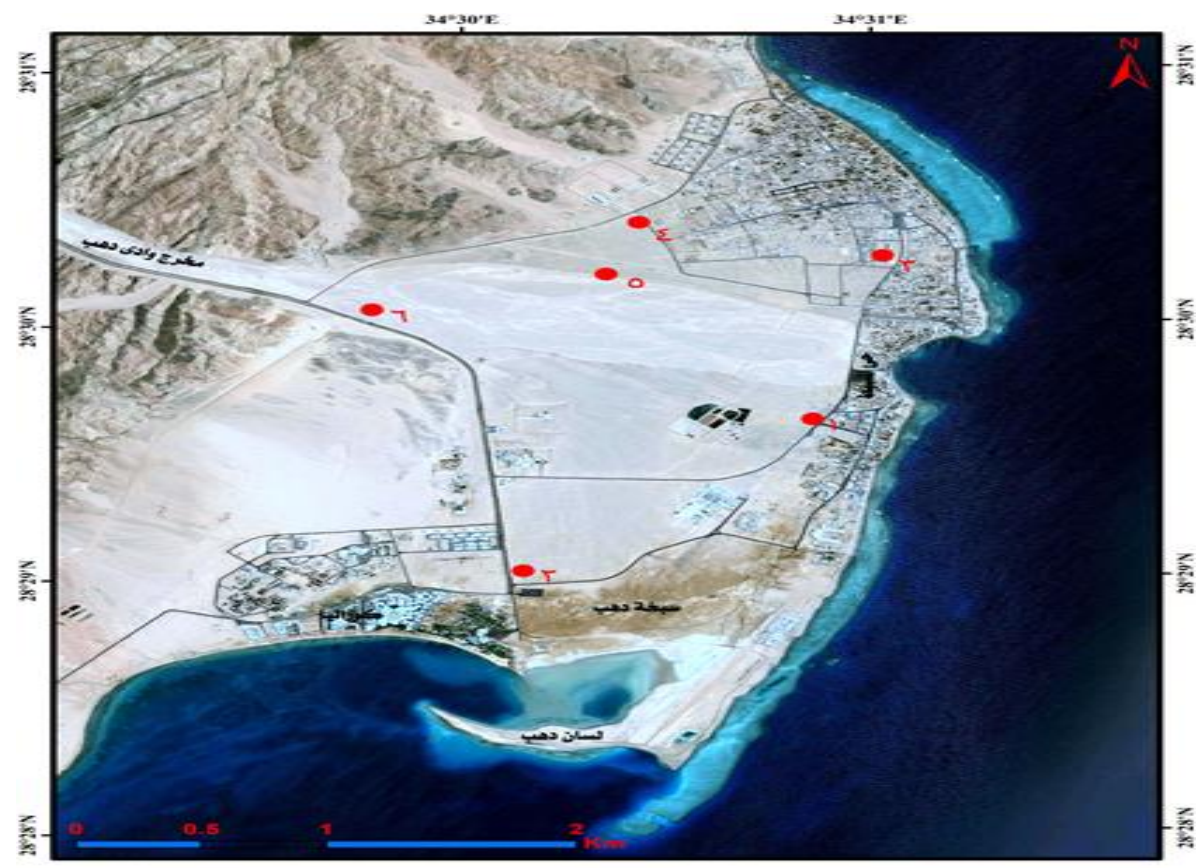

Fig. 9 : Wadi Dahab alluvial fan

The fifth section ass an average thickness of $32 \mathrm{~cm}$ and consists of small and medium-sized rough, semi-circular deposits similar to the deposits of the third section, but the flow of the joints of this section was stronger. The sixth section has an average thickness of $35 \mathrm{~cm}$, and consists of large deposits of large size of large clams and gravel. This indicates the strength of the flow and the short period of time associated with it, and near the source of sediment. 


\subsection{Subsurface Geoelectric Sections}

These sections extend northeast- south west and northwest southeast directions in the selected main streams where the thickest expected sedimentary interval. Figure 10 constructed due four VES's 19, 18, 17 and 16. It indicates the presence of five main geoelectric units reflecting five sedimentary layers. The first layer comprises very high resistivity valued and thin thickness reflects the dray coarse surface cover of sands and gravel.

The second unit of lower resistivities (less than 15 ohm.m) and thickness ranges from $(47-79 \mathrm{~m})$ this unit indicates a silty sand layer when calibrated with borehole data. The third unit has resistivity values ranges from (60 to $407 \mathrm{ohm} . \mathrm{m}$ ) and thickness ranges from (60 m to $85 \mathrm{~m})$. This thick layer reflects a dray zone of sandy and gravely facies.

The fourth unit of low resistivity, (2.5 - 29 ohm.m) and undefined thickness along most of the profile reflect the saturated zone of sandy facies. Moreover, the fifth unit of very high resistivity values appeared only beneath VES no. 18 and reflects the presence of basement rock. Structurally the area was affected by to faults along this profile.

The most significant features in that section are the effect of the faulting which caused rising up of the strata beneath the VES no. 18 where the basement rocks was detected at depth of about $180 \mathrm{~m}$ as an intrusive due to two parallel and reverse faults, also, the great thickness of the second layer under VES's 17 and 19 that reflects good basinal shape suitable for surface water accumulation can infiltrates downwards.

Figure 11, extends parallel to the previous one and passes through VES's 14, 15 and 32 and indicates four geoelectric units of different resistivity values and thicknesses. The first unit of surface gavely layer. The second unit has lower resistivity comprises less than $10 \mathrm{~m}$ thickness and reflects the shalley sediments. The third unit indicated high resistivity (37 to 283 ohm.m) and thickness reached about $(90 \mathrm{~m})$ reflecting the dry sandy larger with some clay intercalation beneath VES no. (32). Moreover, the fourth unit of low resistivity value $(1.5-25 \mathrm{ohm} . \mathrm{m})$ reflects the saturated sandy layer. 


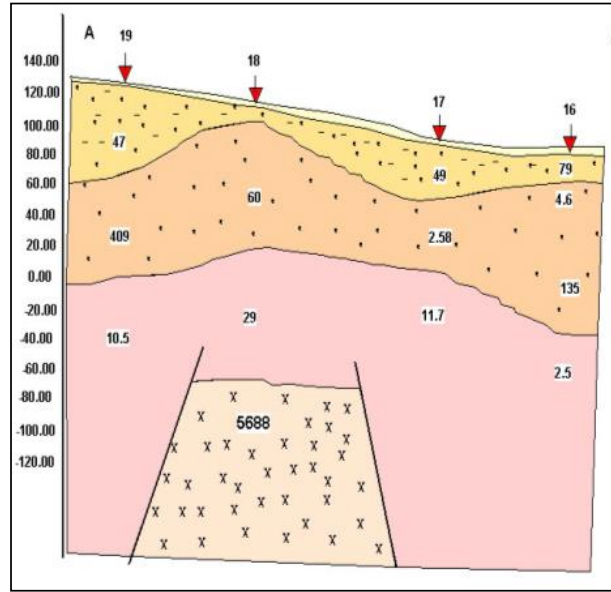

Fig. 10. Geoelectric section A-A

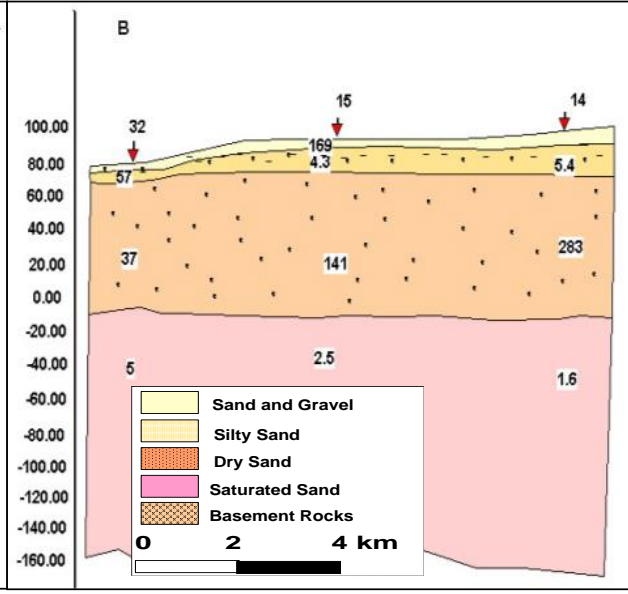

Fig. 11. Geoelectric section B-B

The cross-section C-C, (Fig. 12), investigates to a depth of about $(260 \mathrm{~m})$ and indicates five geoelectric units of different true resustivities and thickness.

The third layer in this section comprises resistivity values range from (21 to 68 ohm.m) and thickness reaches about $(110 \mathrm{~m})$. This unit is interpreted as a dry sandy layer. The fourth unit has resistivity values ranges from (8-20 ohm.m) and great thickness. This unit is interpreted as water bearing sandy layer. Beneath VES no. 13, at depth of about $260 \mathrm{~m}$, the basement rocks of the fifth unit appear of very high resistivity due to a normal fault between VES 13 and VES 30.

The section J-J, (Fig. 13) extends to the northeast and the east of the area. It represents the same five geoelectric units of different resistivity and thickness. The most significant feature in this sections is the high basement surface beneath VES's 40 and 41 due to faults expected between VES 41 and 42. These two faults act as a natural barrier controlling the groundwater accumulation at this location. Moreover, the thickness of the water bearing layer increases toward northwest and decreases to the southeast. 


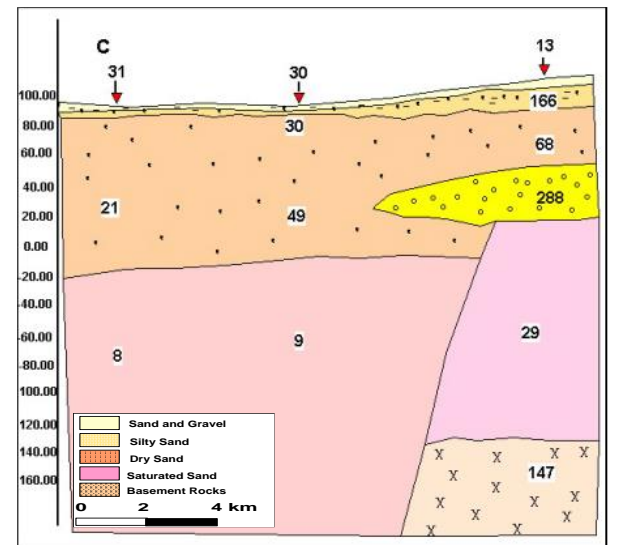

Fig.12. Geoelectric section C-C

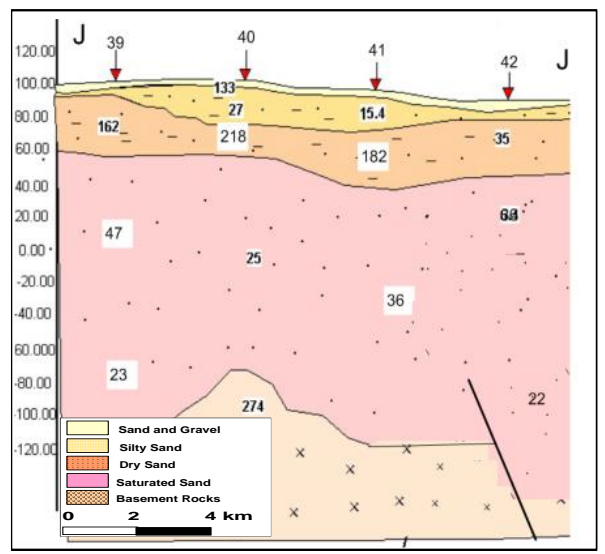

Fig.13. Geoelectric section J-J

\subsection{Depth map of the upper water bearing layer}

This map was constructed as a result of quantitative interpretation of the resistivity measurements in the form of resistivity, thickness of the upper dry zone. It indicates the depth to the third geoelectric units which was considered as a water bearing zone (Figure 14). It indicates that the depth of this layer ranges from $40 \mathrm{~m}$ to $75 \mathrm{~m}$ from the ground surface according the topography of the underlying strata. the most represented feature in this map is the grabbinal contours in the central part of the area that comprises great sedimentary section. This confirm the effect of structural effect on groundwater accumulation.

\subsection{Thickness map of the Water Bearing zone}

This map represents the total thickness of the water bearing zone of the investigated interval. It indicates that this thickness distribution varies from the east to west and ranges from $35 \mathrm{~m}$ to $70 \mathrm{~m}$. the great thickness of this zone lies in the central and eastern parts of the study area while, this zone has a thin thickness at the western and northern parts of the area. (Figure 15). 


\section{Conclusion}

The surface studies indicated that Wadi Dahab basin area reached about $2050 \mathrm{~km} 2$, and its fan area reached almost $7.7 \mathrm{~km} 2$, the relief graduated from 0 near the coast line to 2481 in the southwestern parts of the basin. The basin includes many land forms of various origins, mostly due to the erosion and sediment by runoff water. The most important geomorphologic features are; streams, alluvial cones, isolated hills and alluvial fans.

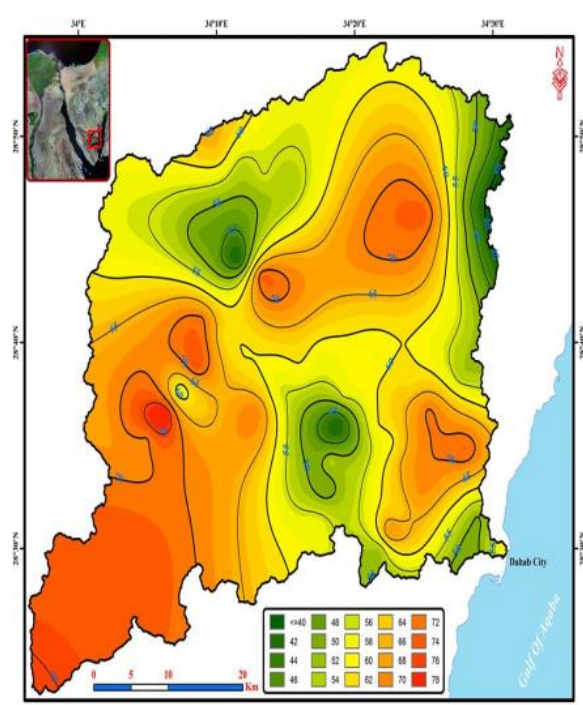

Fig. 14 Depth map of the Upper Water

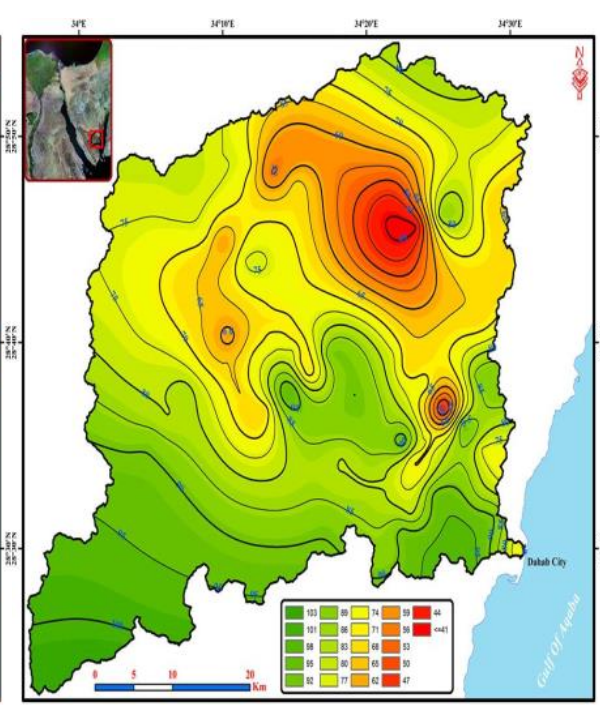

Fig. 15 Thickness map of the Water

The area consists of high complex and complex igneous rocks and metamorphic rocks intersected by many faults differs in their orientation and extends; this complicated structure affected on the directions of different wadis. According to the morphometric analysis and climatic conditions, the total volume of water reached about 25.6 million $\mathrm{m} 3$ / year. The soil of wadi Dahab alluvial fan consists of sand, gravel and limestone.

The southwestern coastal area of the Gulf of Aqaba where the study area is located was subjected to surface geophysical geo-electric resistivity survey and interpretation to identify the subsurface rock sequence, waterbearing layers, and shed more light on the structural trends affecting 
groundwater potentiality and the depth of the sedimentary cover in the selected wadis.

Results of resistivity interpretation indicated a remarkable variation in the thickness of sedimentary rocks in the study area. The thickness of sedimentary section increases at the northwestern and central parts of the study area where the graben structures were exist. This thickness has a minimum value of about $50 \mathrm{~m}$ in the southeastern corner and a maximum value of about $200 \mathrm{~m}$ at the middle part of the study area. Results of electric resistivity soundings indicated that, the study area is characterized by the presence of five main geoelectric resistivity layers arranged from top to bottom as follow; 1) the top surficial layer was interpreted as the dry surface cover of sand and gravels with thin thickness 2) the second layer was interpreted as silty sand layer; with thickness between 5 to $35 \mathrm{~m}, 3$ ) the third layer was also interpreted as dry sand and has thickness ranges from 5130 $m, 4)$ the third layer was interpreted as saturated sand and was considered as the water bearing zone of the investigated interval. Its thickness ranges between 50 and more than $200 \mathrm{~m}$. 5) the fifth layer which is considered as the base of the investigated interval was interpreted as basement rocks.

The general inspection of resistivity sections also, the geological setting indicated that, the area under investigation was dissected by numerous faults. The first major structural trend in the study area in the NESW direction. This trend related to the Gulf of Aqaba trend. The second major structural trend in the NW-SE direction related to the Gulf of Suez trend and is represented by faults. The western and central parts of the study area can be considered as a graben structures where it's bounded by two opposite normal faults. These localities act as a good basin for groundwater accumulation which belongs to the lower sandstone series or "Abu Thora" Formation and it can be considered as the best location for drilling groundwater wells.

Moreover, general inspection of resistivity section indicated that the area was dissected by numerous faults mainly in northeast- southwest and northwest- southeast directions which confirm the lineament map. These faults play an important role in groundwater flow and movement in the study area. It is clearly noticed that the resistivity values of the water bearing layer along the cross-sections perpendicular to the Gulf doesn't 
increase toward the Gulf due to the effect of the northeast-southwest faults existed which act as a natural barrier preventing sea water intrusion.

\section{REFERENCES}

Apparao, A. (1991): Geoelectric profiling. Geoexploration, 27, pp. 351-389.

El Agami, N. L. (1996): Geology and radioactivity studies on the Paleozoic rock units in the Sinai Peninsula, Egypt. [Ph.D. Thesis], Faculty of Science, Mansoura University, Egypt.

EGSMA (Egyptian Geological Survey and Mining Authority) (1993): Geologic Map Sinai, Egypt (scale 1:100 000).

Flathe, H. (1976): The role of a geologic concept in geophysical research work solving hydrogeological problems. Geoexplor., v. 14, 195 - 206 pp.

Graf, W.L., (1988): Fluvial Processes in dryland river, springer-Verlag, berlin.

Hall, S. A., 1979: A total intensity aeromagnetic map of the Red Sea and its interpretation: USGS, Saudi Arabian project Report, pp 265-275.

Hume, W.F., (1906): The Topography and Geology of the Peninsula of Sinai. Geological Survey, Cairo.

Interpex Limited 1996: RESIX-PLUS, Resistivity data interpretation software, V. 2. 39. Golden, Clorado USA.

Khadra,M. S. M. A.(2008): Impact of geomorphology setting on the environmental developmental of the southern area of Gulf of Aqaba, Egypt,M.Sc. Thesis,Mansoura Uni., Fac. Sci.

Koefoed, O. 1979 : Geosounding Principles": 1. Resistivity Sounding Measurements. Elsevier scientific publishing company. Amsterdam. Oxford-New York. pp. (1-3,20-65).

Linsley, R.K., Kohler, M.A., and Phulhus, J.L., (1982): Hydrology for engineers, London.

Parasnis, D. S. (1979): Principles of applied geophysics. Champan and Hall, Halsted Press Book, John Wiley and Sons, New York.

Ravat, D., (1996).Analysis of the Euler method and its applicability in environmental magnetic investigations, Journal of Environmental Engineering Geophysics, 1, 229-238,.

Reid, A. B., J. M. Allsop, H. Granser, A. J. Millett, and I. W.(1990). Somerton, Magnetic interpretation in three dimensions using Euler Deconvolution, Geophysics, 55, 80-90, 
Roest, W. R., J. Verheof, and M. Pilkington, (1992). Magnetic interpretation using the 3-D analytic signal, Geophysics, 57, 116125.

Said, R., 1962; The Geology of Egypt, Elsevier publishing Company, Amsterdam, New york.

Strahler, A.N., (1964): Quantitative Geomorphology of Drainage basin and channel network, in chow, V.T., \{editor\}, hanfbook of applied hydrology, newyourk, PP. 39-76.

Surour, A.A., El-Kammar, A.A., Arafa, E.H., and Korany H.M., (2003).Dahab stream sediments, southeastern Sinai, Egypt: a potential source of gold, magnetite and zircon. Journal of Geochemical Exploration, 77, 25-43.

Telford, W. L. Geldart and R.sheriff, R. (1990): Applied geophysics. Second Ed., Cambridge Univ. Press, 660 p.

Thompson, D. T., (1982). EULDEPTH; A new technique for making computer assisted depth from magnetic data, Geophysics, 47, 31-37

U.S Soil conservation services, (1972): hydrology sec.4, national engineering handbook, Washington D.C.

Zohdy, A.R., G. P .Eaton and D. R. Mabey 1974: Application of surface geophysics to groundwater investigations. USGS techniques of waterresources investigations. Book 2 Chap., 116pp. 